\title{
Kurgusal Mekanlarda Morfogenez Etkisinin İncelenmesi
}

\author{
Almila BULU1 ${ }^{1}$, Emre KAVUT²
}

Öz

Morfogenetik Tasarım, doğadaki evrim sürecine benzer bir işleyiş dahilinde ve genetik algoritmalar vasıtasıyla üretilmiş, kendi kendine organize olup büyüyen, gelişen biçimlerin üretimini gerçekleştiren bir tasarım sürecini kapsamaktadır. Bu çalışma evrim, mutasyon, doğal seçilim, morfogenez gibi kavramların mimarlık ve sinemadaki kurgusal mekanlardaki karşılıklarını ortaya çıkarmayı amaçlamaktadır. Morfogenezin mimaride kullanılığı "The Interactivator" modeli incelenmiştir. Morfogenez kavramının sinema alanındaki karşılığı ise kurgusal mekân üzerinden incelenmiştir. Kurgusal mekanların yoğunluklu olarak kullanıldığı türün bilim kurgu sineması olması sebebiyle araştırmalar bu tür üzerine yoğunlaştırılmış ve "Annihilation" filmi incelenmiştir. Araştırmanın hipotezi; mimarlık ve sinema disiplinleri gibi farklı alanların doğadaki evrimsel süreç ve morfogenez kavramlarını benzer şekilde kullandığı ve farklı disiplinler olmasına rağmen aynı kaynaklardan beslenebildiğidir. Çalışma sonucunda; sanat ve tasarım alanlarında, biyoloji biliminin, gerek mimarlık gerek sinema disiplinlerinde benzer kullanım alanları ve etkisi olduğu görülmüştür.

Anahtar Kelimeler: Morfogenetik Tasarım, Mekan, Bilim Kurgu, Sinema

\section{Research on Morphogenesis Effects in Fictional Spaces}

\begin{abstract}
Morphogenetic Design involves a design process that provides self-organising and selfgrowing forms generated by genetic algorithms in a concept similar to the evolutionary process in nature. The aim of this study is to demonstrate equivalents of biological concepts such as evolution, mutation, natural selection and morphogenesis in fictional spaces in the field of architecture and cinema. Subsequently, to propose a concrete example of Morphogenetic Architecture, "The Interactivator" is chosen as a model in which morphogenesis is used. The equivalence of the concept of morphogenesis in the field of cinema is examined through the fictional space. Since the genre in which fictional space is used extensively is science fiction cinema, researchers in this field focus on this genre and the film "Annihilation" was studied. The hypothesis of the research is that different fields such as architecture and cinema use the concept of evolutionary process and morphogenesis in nature in a similar way, although architecture and cinema are different disciplines, they can be inspired by the same sources. The result of the study is that biological science has a similar use and influence on the field of architecture and cinema.
\end{abstract}

Keywords: Morphogenetic Design, Spatial, Sci-Fi, Cinema

\footnotetext{
1 İstinye Üniversitesi, Güzel Sanatlar Tasarım ve Mimarlık Fakültesi, İç Mimarlık Bölümü, İstanbul

${ }^{2}$ Mimar Sinan Güzel Sanatlar Üniversitesi, Mimarlık Fakültesi, İç Mimarlık Bölümü, İstanbul

*ilgili yazar/Corresponding Author: almilabulu03@gmail.com

Gönderim Tarihi / Received Date: 19.04.2021

Kabul Tarihi / Accepted Date: 22.11.2021
} 


\section{Giriş}

Bu makale, doğadaki evrimsel işleyişin ve içerdiği çeşitli kavramların mimari, görsel sanat ve kurgusal mekanlardaki ortak kullanım temalarını görebilmek adına önemlidir. Mimarlık, tarih boyunca birçok farklı açıdan ve yöntemle doğadan ilham almış ve doğayı kullanmıştır. Bu esinlenmenin kaynağı biçimsel ve strüktürel yönden olabildiği gibi doğadaki işleyişin ve akıp giden sürecin mantığını kapsayacak şekilde de olabilmektedir. Hesaplamalı Mimarlık'ın alt başlıklarından biri olarak kabul edilen Morfogenetik Tasarım çalışmanın odak noktası olarak belirlenmiştir. Hesaplamalı tasarım algoritmalar aracılığıyla tasarım yapmak şeklinde özetlenebilmektedir. Doğal seçilim ve morfogenez kavramları üzerinden şekillenen Morfogenetik Tasarım'ın karşılığını mimarinin yanı sıra, görsel sanat ve sinema disiplinlerinde de görmek mümkündür. Bilgisayar temelli form yaratımı ve formların transformasyonunu içeren bir süreç olan yaklaşım çeşitli kaynaklarda Dijital Morfogenetik, Dijital Morfogenez olarak da tanımlanmaktadır. Mimarlık, biyoloji ve yazılımın ara kesitinde yer alan Dijital Morfogenetik Tasarım'a, çalışma boyunca mimarlıkla beraber, bahsedilen bu iki disiplin üzerinden bir bakış sunulmuştur. Tasarım ve mimarlık disiplini, merkezine insanı konumlandırmış olduğundan insan ile etkileşim halinde olan konulardan ve bu alanlardaki evrilmelerden direkt etkilenme durumu söz konusudur. Her dönem değişen teknoloji, demografik, ekonomik, çevresel koşulları ve intiyaçları doğrultusunda kendi mimari tarzını yaratmaktadır. Biyoloji biliminin ve özellikle evrim ve morfogenez kavramlarının Hesaplamalı Tasarım yöntemleri gibi, teknolojinin sağlayacağı imkanlarla geleceğin tasarımını daha da yoğun şekilde biçimlendirmesi beklenmektedir. Mimari mekanlar oluşturulurken özellikle bilim kurgu ve fantastik sinemanın ütopik felsefesinden etkilenileceği öngörüler arasındadır.

Geleceğin mimarisinde günümüzün fütüristik olarak adlandırdığı tasarım yaklaşımlarının artmasıyla kurgusal mekanlar ve reel mimari üretimler arasındaki sınırların muğlaklaşacağı beklenmektedir. Geçmişin ütopya olarak kabul edilen fikirleri ve tasarım kurguları günümüzün realitesini ya da geleceğin olası mimarisini yaratabilme ihtimalini barındırmaktadır. Tam da bu noktada, içinde bulunduğumuz dünyada reel olarak bulunmayan kurgusal mekanlara çokça rastladığımız bilim kurgu sineması içerdiği sürrealizm, ütopya ve fantastik kurgular ile evrimsel, genetik, morfogenetik olarak sıralayabileceğimiz fütüristik tasarım ve fikirlerle kesişmektedir. Çalışmada, gerek mevcut ilişkileri gerekse gelecek mimari tasarım kurgularını şekillendirme konusunda etkin rol oynayacağı düşüncesiyle genetik, kurgusal mekan ve mimarinin kesişim noktalarının incelenmesi amaçlanmaktadır. Çalışma, morfogenetik etkili mimari ve seçilen örneğe dair literatür araştırmalarını ve kurgusal mekandaki mutasyon, morfogenez etkilerinin görülebilmesi adına "Annihilation" filminin konu bağlamında incelenmesini kapsamaktadır. Çalışmada, gerek mevcut ilişkileri gerekse gelecek mimari tasarım kurgularını şekillendirme konusunda etkin rol oynayacağı düşüncesiyle genetik, kurgusal mekan ve mimarinin kesişim noktalarının incelenmesi amaçlanmaktadır. Çalışma, morfogenetik etkili mimari ve seçilen örneğe dair literatür araştırmalarını ve kurgusal mekandaki mutasyon, morfogenez etkilerinin görülebilmesi adına "Annihilation" filminin konu bağlamında incelenmesini kapsamaktadır.

\section{Morfogenetik Tasarımın Mimari ve Görsel Sanatlar Üzerinden İncelenmesi}

\subsection{Bilgisayarın Mimari Alandaki Dönüşümü}

Gelişen teknolojinin sağlamış olduğu imkanlar dahilinde, bilgisayar programlarının ve yazılımlarının salt mimari sunum aracı olarak kullanılması bir adım öteye taşınarak formun, mekânın kurgulanma aşamalarında kullanımı söz konusu olmaya başlamıştır. 
Mimarlık alanı içerisindeki üretimlerde, teknolojinin ilerlemesine paralel olarak algoritmalar ve mimarların yönlendirmesiyle bilgisayar, süreci tasarlayan bir araç haline gelmiştir. Dolayısıyla rasyonel geometrik biçimlerin yaratımı ötesinde, insan gücünün izin vermediği eğrisel, organik biçimlerin hesaplanması ve çizilmesi oldukça kolay hale gelmiştir. Küre, silindir gibi öklidyen geometrilerin yanında, kompleks eğrisel geometrilerin de aynı şekilde üretilebilmesinin yolunu açan Hesaplamalı Tasarımlar ile sonsuz çeşitlilik sunan alternatifleri içeren modüler formlara ulaşılabilmektedir (Ahmed, 2015, s.76). Mimaride Morfogenetik Yaklaşımlar dahilinde, bilgisayar yapının biçimlenişinde etkin olan, yapıyı oluşturan ve dönüştüren bir misyon yüklenmektedir (Roudavski, 2009, s.348). Dijital Hesaplamalı Tasarım, geleneksel mimarlık anlayışının taşıdığı statik strüktür kullanımını bilgisayarı tasarıma dahil ederek değişken ve çeşitlilik içeren formların kullanılmasına evriltmiştir. Bilgisayar yazılımları ve algoritmalar doğrultusunda oluşturulan tasarım yöntemlerinden biri bu çalışmanın konusunu oluşturan Morfogenetik Mimari yaklaşımdır.

\subsection{1. Üretken Tasarım Sistemleri}

Üretken Sistem Yaklaşımları'ndan biri olan Biyolojik Üretken Sistemler, doğadaki karmaşık organizmaların prensiplerini mimari form yaratımı ve dönüştürülmesi için kullanmaktadır. Sonuçta elde edilen mimari formdansa o formun üretim süreci üzerine yoğunlaşılmaktadır. Üretken Sistem metotlarından biri olan Algoritmik Sistemler belirli strüktürler, sunumlar ya da içerik üretimi konusunda zorlamada bulunmayan bir çalışma ortamı sunduğu için mimarlar tarafından tercih edilmektedir. Algoritma ile üretim yöntemi Üretken Sistem Yaklaşımlarının diğer metotları ile karşılaştırıldığında daha sık kullanılmaktadır. Bu sebeple çalışmada, Formalizm başlığı altındaki Lindenmayer sistemleri, hücresel otomasyon, fraktaller gibi Üretken Tasarım Sistem Yaklaşımları'nın açıklamalarına yer verilmemiştir. Catia, Generative Components ve SolidWorks gibi programların kullanımını içeren Parametrik Sistemler de algoritmik sistemler içinde yer almaktadır. Üretken Tasarım sürecinde bir fikir üzerine tasarımcı kuralları, algoritmayı belirlemekte daha sonra bu kurallar kaynak koda dönüştürülmektedir. Sonucunda elde edilen veri tasarımcı tarafından değerlendirilmektedir. Üretken Tasarım süreci dört temel bileşenden oluşmaktadır: girdi olarak adlandırılan bir başlangıç noktası ve parametreler, algoritma ve kuralları içeren bir üretken mekanizma, çıktı olarak adlandırılan değişken jenerasyonlar ve ulaşılan en iyi değişkenin seçimi. Bu dört aşama sonuçlanana kadar somut bir veri elde edilemediği için Üretken Sistemler temsili bir yapıdan ziyade bir yaratım sistemi olarak tanımlanmaktadır (Ahmet, 2015, s.8-9). Parametre ve algoritmaları içeren hesaplamalı, üretken yöntemleri sayesinde alışılan form ve temsil ilişkileri yıkılarak mimarlara yeni bir yol açılmıştır. "Form yapımı" mentalitesini "form bulma" olarak değiştirmiştir.

\subsection{Morfogenez Kavramı}

Kökeni biyoloji bilimine dayanan, 19.yy'da ortaya çıkan bir kavram olan morfogenez Yunanca "morphe" biçim ve "genesis" yaradılış manasına gelen kelimelerden türemiştir (İçmeli, 2014, s.1). Doğada morfogenez bir canlının dış etkiler neticesinde evrimsel gelişim ve büyümesine karşılık gelmektedir. Biyolojik formların hücresel yapısından, dokularının biçimlenişine, dokuların organ ve organizmanın bütününü oluşturmasına kadar transformasyonun birçok seviyesi ile ilgilidir (Ahmet, 2015, s.7). Morfogenezin biyoloji alanındaki kullanımına genel bir çerçeve üzerinden bakıldığında, bir organizmanın gelişmesini sağlayan biyolojik süreç ve gelişimin birçok yönünü işaret etmektedir. Fakat daha spesifik olarak kullanıldığında, hücre ve dokuların belirli bir biçim alması anlamına gelmektedir. Organizma geliştikçe dokularında meydana gelen yapısal farklılaşmaları tanımlamak için ya da bu yapısal değişimlerin arkasında yatan mekanizmaları ifade etmek için kullanılmaktadır (Roudavski, 2009, s.358). Canlı organizmalar çevresel koşullara uyum sağlayabilmek için evrimsel işleyiş içerisinde 
başkalaşım geçirirler, fiziksel çevreye adapte olmalarını sağlayan değişim morfolojik eylemler sayesinde mümkün olmaktadır. Doğal seçilim, adaptasyon, mutasyon, evrim gibi kavramları içeren morfogenezin amacı organizmanın farklılaşarak yeni biçimini almasını sağlamaktır.

\subsection{Morfogenezin Mimarlık, Görsel Sanat ve Kurgusal Mekanlardaki Etkileri 2.3.1. Morfogenetik Mimarlık}

Morfogenez kavramı biyoloji alanının yanında mühendislik, sanat ve mimarlık gibi farklı disiplinler içerisinde de kullanılmaktadır (Ahmet, 2015, s.72). Bilgisayar odaklı mimari tasarım yaklaşımı içinde morfogenez, tasarım sürecinde bir rehber görevi görmektedir (İçmeli, 2014, s.1). Mimari yapılar çoğunlukla statik, kalıcı ve masif kütleler olarak bilinmesine rağmen 20.yy ile başlayan, doğanın örnek alınarak mimaride kullanılmaya başlanması ile çeşitli değişimler yaşanmaya başlamıştır. Bu yaklaşıma göre mimari formlar, tıpkı doğada belirli koşullar altında yaşayan ve bu koşullara adapte olan canlı organizmalar gibi doğal güçler ile etkileşimli olarak dönüşmekte ve bu etkiler doğrultusunda adapte olabilmektedirler (Kachri, 2009, s.9). Mimaride morfogenez hesaplamalı araçlar aracılığıyla, bir yapının formunun tasarlanmasında esin kaynağı olarak kullanılmaktadır. Biyolojik bir kavram olan morfogenezin mimariye aktarımı sayesinde doğada mevcut bulunan sorunlar karşısında üretilmiş çözümler mimari alandaki problemlere yanıt vermek için kullanılabilmektedir. Sadece mevcut sorunlara odaklanmanın ötesinde, doğadaki işleyiş metodunu kullanarak çeşitli potansiyel fonksiyonlar ve çözümler sunabilmektedir (Ahmed, 2015, s.75).

Mimaride Dijital Morfogenez kullanımı sürecinde, mimari biçim doğadaki oluşumlardan etkilenilerek oluşturulduğundan doğadaki morfogenez süreciyle analojik ilişkiler içermektedir. Bu yaklaşımda mimari konseptler Hesaplamalı Tasarım kuralları dahilinde ifade edilmekte ve yine bu kurallar dahilinde test edilmektedir bir başka deyişle; mimari formlar kodlar aracılığıyla üretilmektedir ve simüle edilen bu modeller yine simülasyon ortamı içerisinde performanslarına göre değerlendirilebilmektedir. Dijital Morfogenez kullanımı sayesinde aynı anda birden fazla fonksiyona sahip olunabilmesi, başkalaşabilen ve çok sayıda çeşitliliğe sahip formlara ulaşılabilmesi gibi çeşitli avantajlara sahip olunmaktadır (Roudavski, 2009, s.349). Evrim kavramını odağına alan Dijital Morfogenetik Mimarlık yaklaşımının temeli genetik algoritmalara dayanmaktadır. Genetik kodlamanın felsefesini yapının biçimini oluşturmak değil, içerdiği temel mantığı doğaya göre yaratmak oluşturmaktadır. Genetik algoritmaların temel özelliği doğada reprodüksiyon, mutasyon ve çaprazlamadan sorumlu kromozom benzeri yapılar barındırmasıdır. Bu yapılara çeşitli parametreler kodlanmakta ve süreç boyunca değerleri değişmektedir. Uygunluk kriterine göre seçilen en uygun alternatifler ve parametre değerleri çaprazlanarak verimli özelliklerinin yeni jenerasyonlara aktarılması sağlanmaktadır. Bu sayede, sürecin sonunda en ideal çözüm üretilmiş olmaktadır (Ahmed, 2015, s.82).

Genetik kodlama, doğal seçilim, tekrarlama, morfogenez gibi kavramları içeren mimari yaklaşımda tıpkı doğadaki gibi yetersiz olan ve uygun olmayan alternatifler elenmekte ve en başarılı varyasyona ulaşılana kadar süreç tekrarlanmaktadır. Genetik algoritmalar bir problem karşısında çok sayıda alternatif sunduğu için, elde edilen çözüm popülasyonunun arasından istediğimize en yakın veriler seçilip geriye kalanlar elenerek en iyi sonuca ulaşılmaktadır. Algoritma destekli bu tasarım yöntemi ile hız ve alternatif çeşitliliği açısından geleneksel mimarlık üretimi ile kıyaslandığında verimli bir tasarım sürecine sahip olunmaktadır. Morfogenetik Mimarlık'ın kendi kendine organize olma, kendi kendine yetebilen mekan tasarımları oluşturarak mimariye aktarma, ulaşılabilecek en iyi alternatiflere parametrik tasarım ve genetik algoritmalar dahilinde kısa sürede 
ulaşma ve hızı şekilde transformasyona uğratabilme gibi özellikleriyle geleceğin mimarisinde yerini alacağı öngörülmektedir.

Morfolojik Tasarım başlığı altında yer alabilecek bir yapı olan Araştırma Pavyonu, ICD/ITKE VE Stuttgart Üniversitesi'nin işbirliği çerçevesinde gerçekleştirilmiş bir yapıdır. Biyolog, mimar, mühendis, paleontolog ve öğrencilerin beraber çalışması sonucu iki buçuk yılda inşa edilmiştir (Elshtwei, 2018, s.76). Tasarım içindeki alanlar biyolojik ilkelerden ilham alan Hesaplamalı Mimari Tasarım'ı kullanarak artık üretimi mümkün kılınan sonuçları tanımlamaktadır (Elshtwei, 2018, s.75).

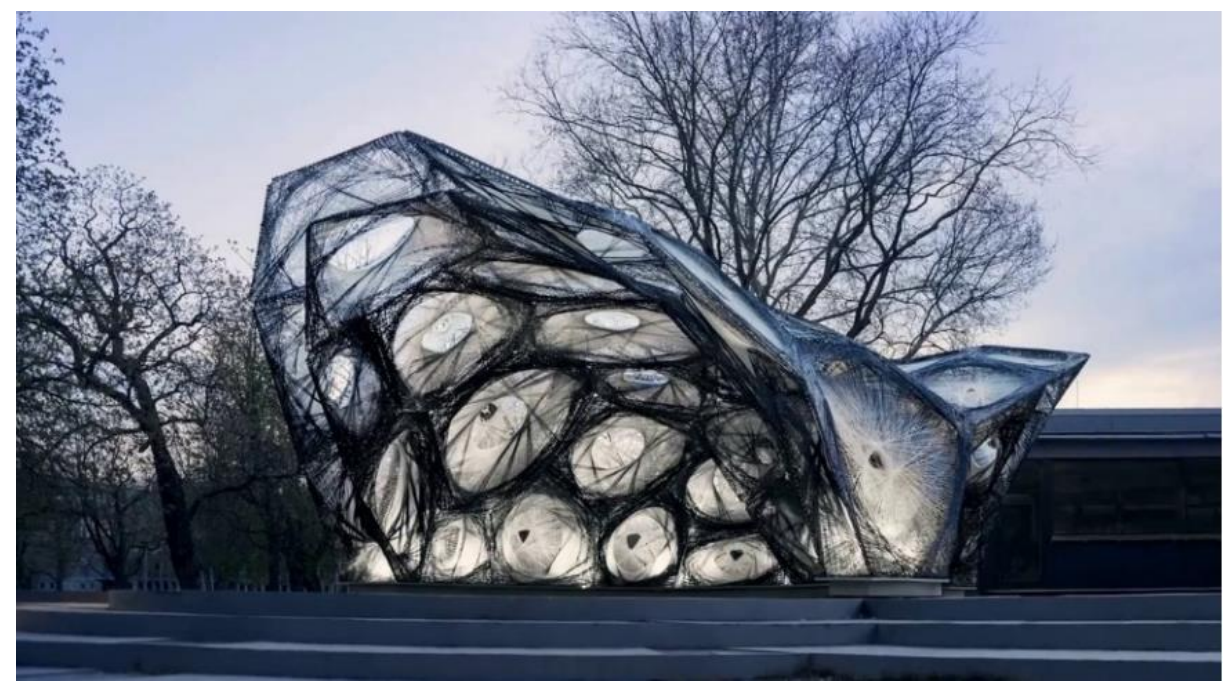

Şekil 1: ICD/ITKE Araştırma Pavyonu 2013-14 (Elshtwei, 2018, s.75).

Yapı, morfolojik prensipleri içeren Hesaplamalı Tasarım çerçevesini izleyerek oluşturulmuştur. Malzemeler ve yapının strüktürü fiberlerden oluşan hafif bileşenlerden oluşmaktadır (Elshtwei, 2018, s.76). Araştırma süresince, Elytron Böceği ve özellikle dış kabuğu olan kitin tabakası üzerinde yapılan araştırmalar, bu ultra hafif yapıların malzeme verimliliği açısından çok kayda değer özelliklere sahip olduğu tespit edilmiş, Pavyonun kabuk, taşıyıcı ve iç mekan olmak üzere bütüncül bir şekilde tasarlanması yolunda faydalanılmıştır (Şekil 1).
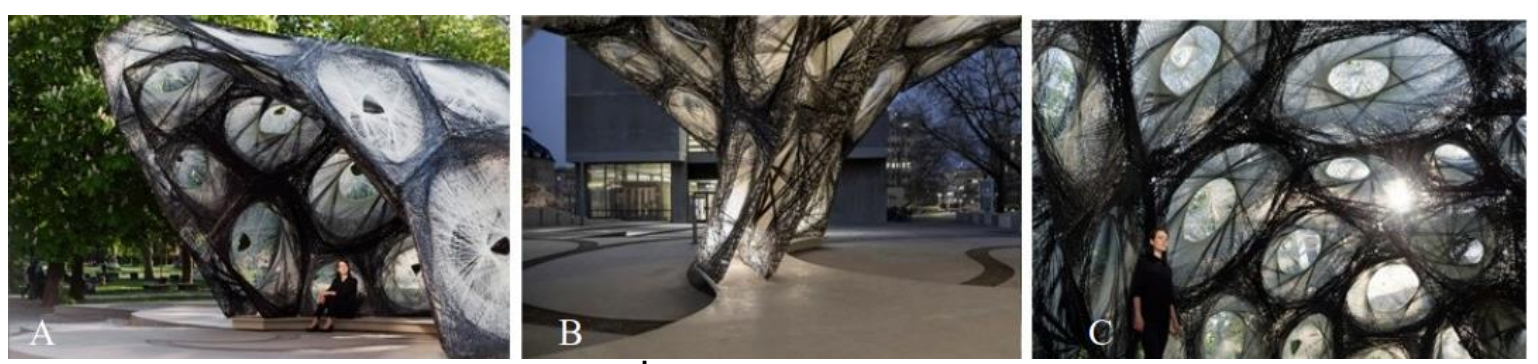

Şekil 2: Araştırma Pavyonu'nun İç Mekan ve Bileşenleri (Elshtwei, 2018, s.76).

Hesaplamalı Tasarım stratejileri kullanılarak ICD/ITKE Araştırma Pavyonu gibi projelerin yaratılması, biyolojik modellerden öğrenilen strüktürel prensiplerin kullanım olanaklarını ortaya çıkarmıştır (Elshtwei, 2018, s.76, 80). Elytron'un biyolojik özelliklerini alarak, hafif malzemeler, iki katmanlı sistemler ve lifli yapılarını sisteme entegre ettikten sonra hesaplamalı süreçlerden geçirilerek final form elde edilmiştir (Şekil 2). Araştırma enstitüleri, Hesaplamalı Tasarım potansiyellerini ve biyolojik ilkelerin mimariye ne kadar başarılı şekilde uygulanabileceğini göstermek için gelecekte bu pavyonlar gibi mimariler inşa etmeye devam edecektir (Elshtwei, 2018, s.76). 
Morfolojik Tasarım dahilinde yaratılmış diğer bir örnek olan Hygroscope, ortamdaki nem seviyesi arttığında herhangi bir ilave sistem, ekipman ya da elektrik olmadan atmosferi havalandırabilmektedir. Proje, herhangi bir ek teknolojiye intiyaç duyulmadan iklim değişikliklerine cevap veren mimari bir sistemdir. Yapının nefes alması ahşabın özelliklerine, maddelerin fiziksel ya da mekanik özelliklerinin, yöne bağlı olarak değişmesi olarak tanımlanan anizotropi ile ahşabın kuruyken nemi emme ve ıslakken atmosfere nemi salma yeteneği olarak tanımlanan higroskopikliğe dayanarak sağlanmaktadır. Neme karşı hassasiyet sayesinde şekil değişiklikleri meydana gelmektedir. Sistemde malzeme olarak, akçaağaç kaplama ile sentetik kompozitlerin kombinasyonlarından oluşturulmuş, tasarım için özel üretilmiş elemanlar kullanıımıştır. Toplamda 4000'den fazla geometrik olarak benzersiz eleman robotik olarak üretilmiştir (Grozdanic, 2012).

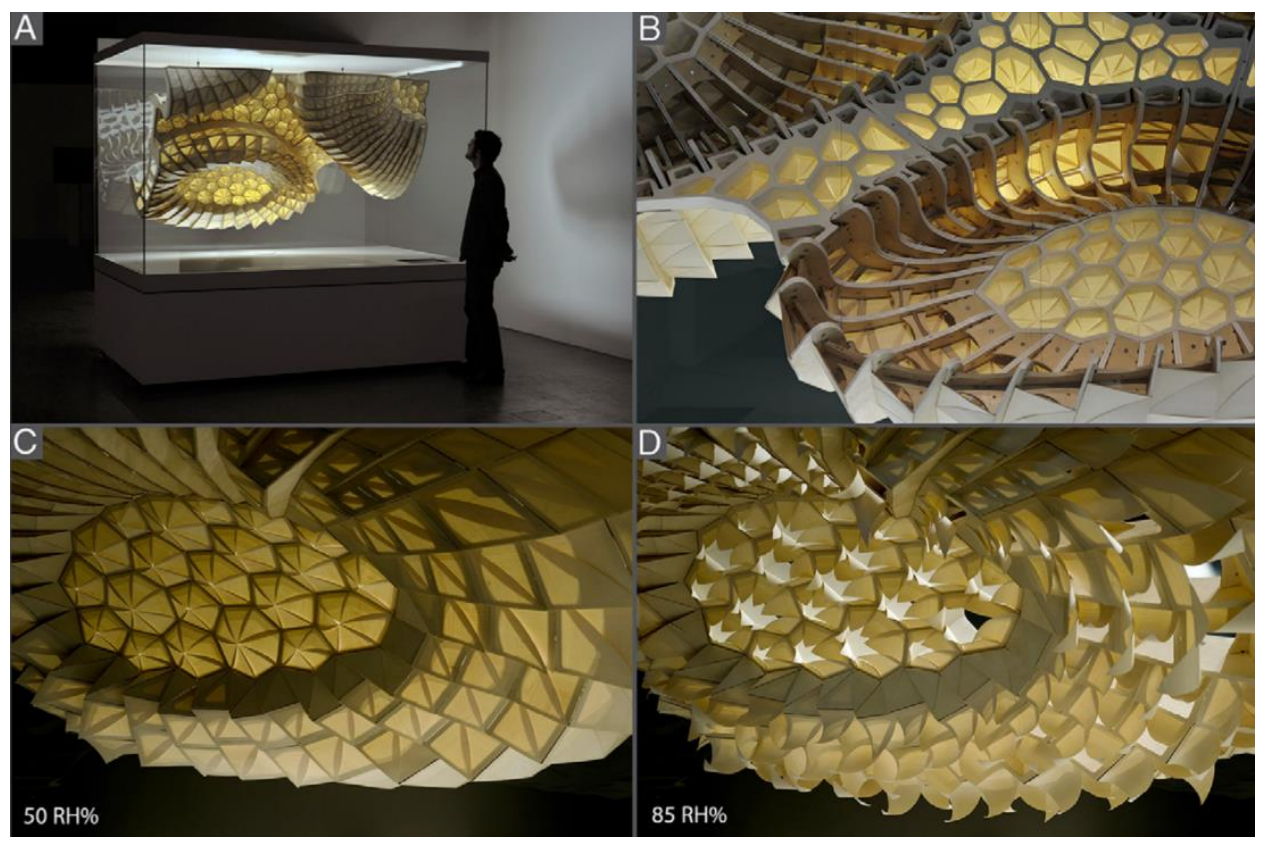

Şekil 3: Centre Pompidou'da Bulunan Hygroscope Enstelasyonu (Reichert, Menges, Correa, 2015, s.64).

Higroskopik malzeme özelliklerinden faydalanılarak çevresel değişikliklere uyum sağlayan Hygroscope otonom bir mimari sistemdir. Teknoloji içermeyen tasarımın mekanik prensipler yerine biyolojik prensipleri izlediği söylenebilmektedir (Şekil 3). Doğada farklı bitki türlerinin sahip olduğu özellik olan higroskopik şekil değiştirme adaptasyonu mimari uygulamalar açısından önemli potansiyeller barındırmaktadır (Reichert vd., 2015, s.50). 


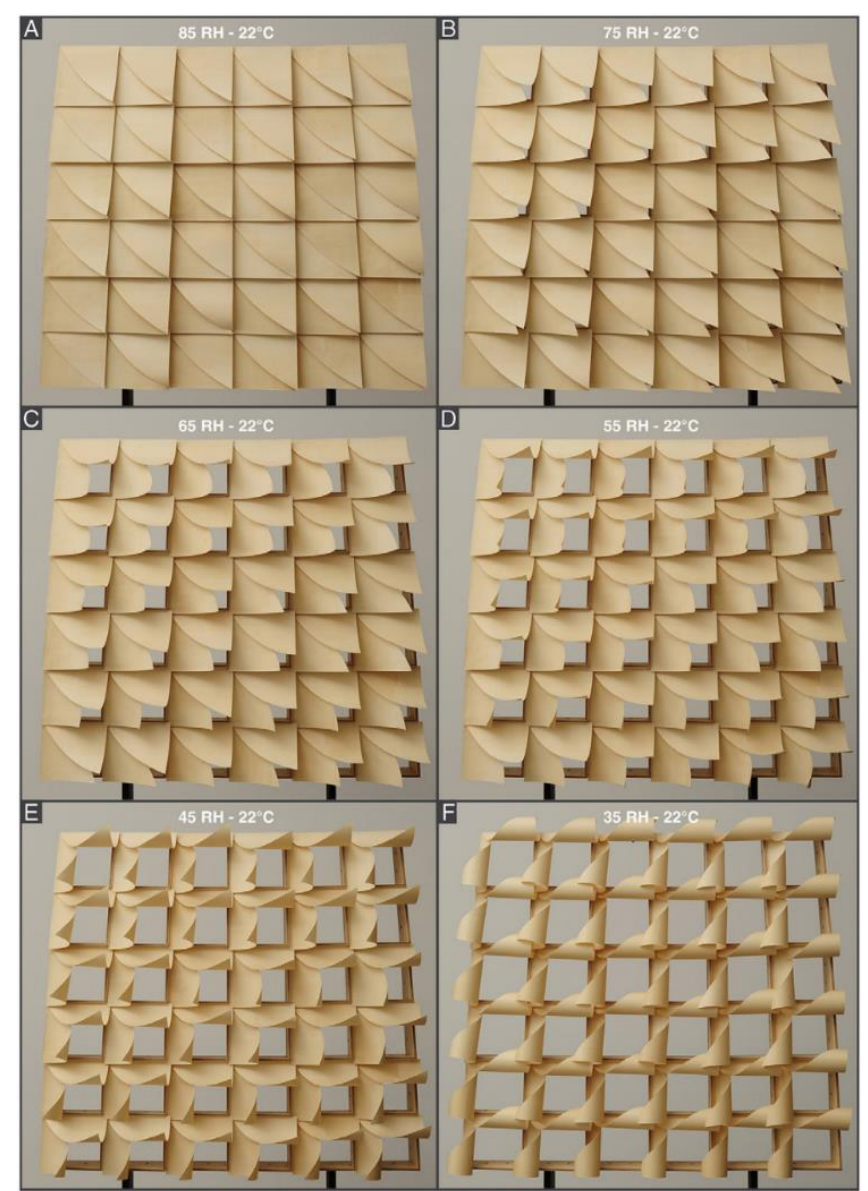

Şekil 4: Denetimli İklim Koşulları Altında Elemanların Laboratuvar Testi (Reichert vd., 2015, s.59).

Ortamdaki nem seviyesindeki genel değişimler yüzeylerin tamamen kapalı A'dan tamamen açık durumda bulunan F'ye kadar homojen bir şekilde açılıp kapanmasını sağlamaktadır. Verilen Hygroscope örneğinde olduğu gibi iklime duyarlı, çevresel koşullara yanıt veren, dinamik hareketler içererek kendini otonom olarak koşullara göre regüle eden, adaptasyon özelliğine sahip mimari projelerin sayısının gelecekte çeşitli faydalar ortaya sunacağı beklenmektedir.

\subsubsection{The Interactivator}

Londra'da 1995 yılında açılan "An Evolutionary Architecture" (Evrimsel Mimarlık) sergisinde, The Interactivator gerek sergideki izleyicilerle etkileşim halinde olan gerek sergi atmosferine cevap veren, evrim geçiren bir tasarımdır. Mekâna yerleştirilmiş sensörler alandaki nem, koku, sıcaklık, duman, ses gibi verileri algılayarak modelin evrimini etkilemektedir. Bununla beraber, izleyicilerin genetik bilgi önerileri de evrimin ilerleme aşamalarını etkilemektedir. İnternet kullanımı devreye sokularak proje bir sonraki aşamaya taşınmıştır. İnternetten katıım sağlayan izleyiciler tıpkı sergi alanında olduğu gibi genetik bilgi girişi yapmaktadır. Diğer bir alternatif olarak, modelin farklı web sitelere indirilmesiyle kopyalarının oluşturulması sağlanmıştır. Farklı evrimsel yollar ile üretilmiş yeni modeller gen havuzuna katkıda bulunması açısından ilk etapta üretilen modele de katkı sağlamaktadır. Son olarak sergiye erişimine izin verilen bir web sitesi aracılığıyla modelin evrimleşme aşamaları gözlemlenebilmekte ve projenin bağlamı anlaşılabilmektedir. Doğal seçilim ve evrim mantığını taşıyan üretken bilgisayar modeli projesinde, ilk iki hafta içinde kromozomlara bağlı olarak üretilmiş dört aile yüz yirmi jenerasyon sonra aynı kromozom yapısını korumuştur (Frazer, 2002, s.35). 


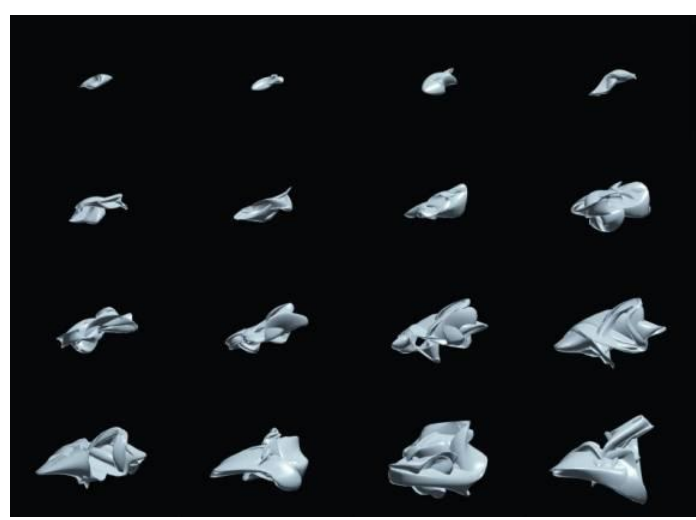

Şekil 5: Üretken Bilgisayar Modeli Projesi Interactivator'ün Dış Etkiler İle Geçirdiği Morfogenez ve Evrimsel Aşamalar (Bentley, 2001, s.270).

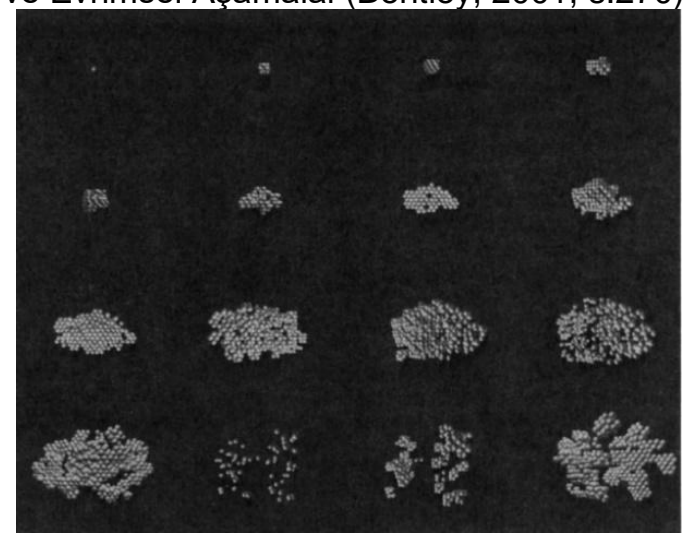

Şekil 6: Genetik Algoritmalarla Kontrol Edilen Veri Hücreleri (Bentley, 2001, s.270).

Üretken-evrimsel tasarım The Interactivator sanal ortamda global bir katılımla doğadaki evrimsel modeli bir mimari form üretme süreci olarak kullanmıştır. Katılımcı kitlesi sayesinde genetik tasarım havuzu içinde bir biyoçeşitlilik yaratılmıştır. Bu biyolojik çeşitlilik genetik algoritmalar vasıtasıyla yeni nesillerin eski nesillerden öğrenmesi sağlanarak oluşturulmuştur (Janssen, 2020). Doğanın sanal bir ortamda simüle edildiği projede, gelişimi belirleyen algoritmalar ile yapay tohumlar çoğalma, mutasyon, morfogenez gibi eylemler sonucunda evrim geçirmiş ve modelleri meydana getirmiştir (Vural, 2015, s.8). Morfogenetik Mimarlık Yaklaşımı'nın içerdiği genetik tekniklerin dış kabuk ya da sadece biçim yaratma için var olmasının aksine temel mantığını form bulma süreci oluşturmaktadır. Sergide henüz sanal olarak gerçekleştirilen bu projenin ileride sanal mekândan gerçek mekanlara aktarılarak gerçekleştirileceği öngörülmektedir.

\subsubsection{Annihilation Filminin İncelenmesi}

Jeff VanderMeer'in aynı isimli romanına dayanan, Alex Garland tarafından yazılmış ve yönetilmiş 2018 yapımı bilim kurgu filmi Annihilation'ın kurgusal mekanlarındaki mutasyon, evrim, morfogenez kavramlarının kullanımı ve etkileri incelenmiştir. Film bir grup bilim insanının, hükümet tarafından karantinaya alınan "The Shimmer" (Parıltı) olarak adlandırılan alana girmeleri ve dünya dışı güçlerin etkisiyle oluşmuş bitki ve hayvan mutasyonlarını kapsayan anomalilerle karşılaşmalarını konu almaktadır. 3 sene önce bir meteorun çarpmasıyla The Shimmer adı verilen bir oluşum meydana gelmiş ve gittikçe büyüyerek sınırlarını genişletmiştir. Eski asker, moleküler biyolog Lena'nın kendisi gibi asker olan eşi Kane The Shimmer'a yaptığı gizli görevden bir sene sonrasında dönmüş fakat hiçbir şey hatırlamamaktadır. Ani gelişen sağlık sorunu sebebiyle çağırdıkları ambulansın yolu güvenlik güçlerince kesilir ve fenerin dolayısıyla The Shimmer'ın yakınında bulunan X Bölgesi üssüne götürülürler. 


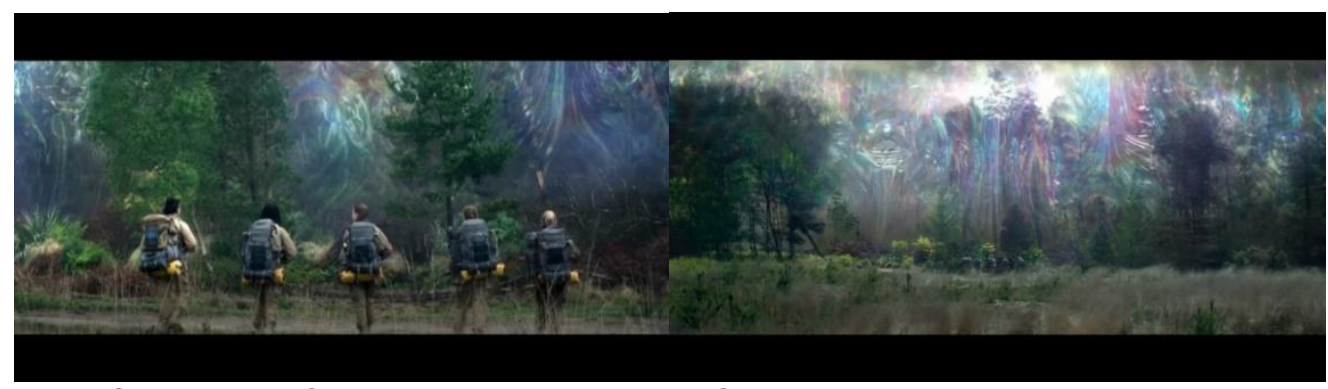

Şekil 7: The Shimmer Filminden Ekran Görüntüleri [00:28:05] - [00:28:16]

Dünya dışı etki sonucunda gelişen bu bölge hakkında teoriler olmasına rağmen kesin bir bilgi yoktur. Bu sebeple biyolog Lena, psikolog Dr. Ventress, fizikçi Rodie Radek, jeomorfolog Cassie Sheppard ve sağlık görevlisi Anya Thorensen'dan oluşan bir ekip The Shimmer'ın ana kaynağı olan fenere gidip gözlem yapmak ve bilgi toplamak üzere bölgeye girerler (Şekil 7).

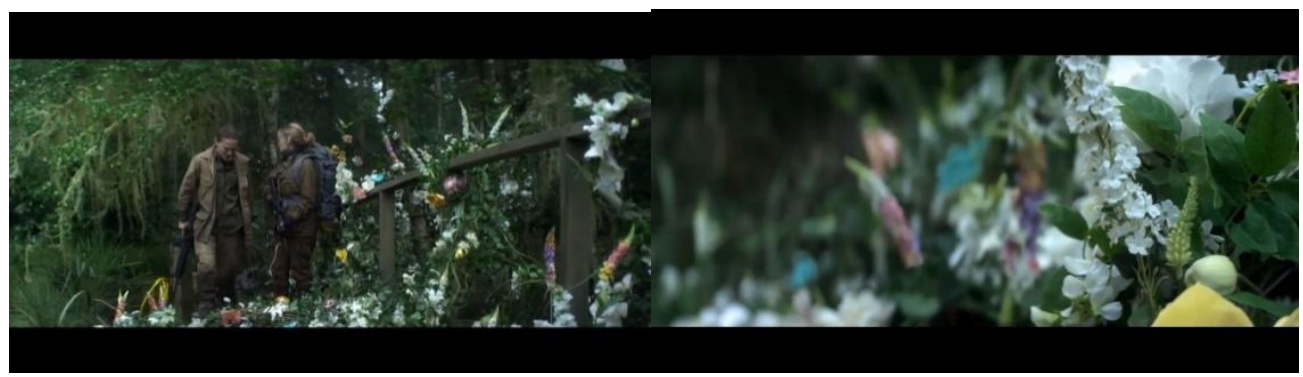

Şekil 8: The Shimmer Filminden Ekran Görüntüleri [00:33:32] - [00:33:55]

Bölge içinde ilerledikçe bitki ve hayvanların normal yapısından farklı olduğunun farkına varmaya başlarlar. Çiçekler aynı dal yapısından çıkmalarına rağmen, aynı bitki farklı türler barındırır. Bölgedeki bir şey gen havuzunda zincirleme mutasyonlara sebep olmakta ve çok şiddetli bir değişim yaratmaktadır (Şekil 8).

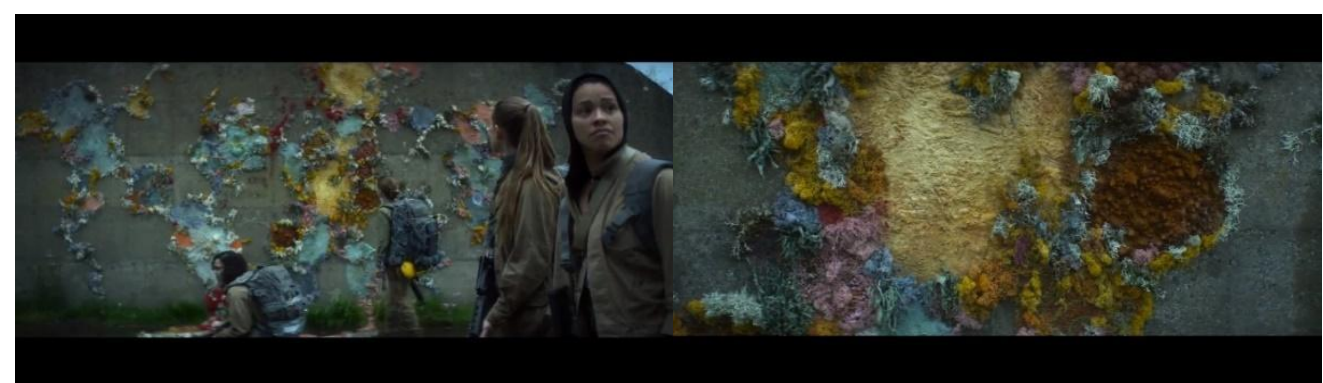

Şekil 9: The Shimmer Filminden Ekran Görüntüleri [00:41:40] - [00:42:00]

Önce hafif olan mutasyonların etkisi, fenere yaklaşıldıkça ağırlaşır. Şekil bozuklukları, formların kopyaları, tekrarlamalar, morfolojik başkalaşımlar görülmeye başlanır. Kendilerinden önceki keşif grubunun üs olarak kullandığı yapının beton duvarlarının üzerinin renkli organizmalarla kaplandığını görürler (Şekil 9). 


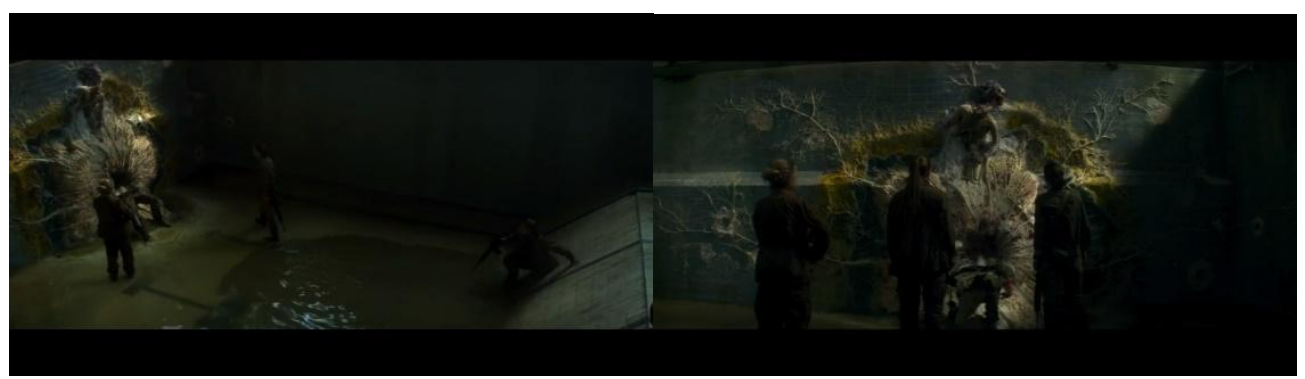

Şekil 10: The Shimmer Filminden Ekran Görüntüleri [00:47:50] - [00:48:04]

Karargâhın cephe yüzeylerini sararak yüzeyi malzeme ve renk açısından başkalaştıran, canlı cansız ayrımını bulanıklaştıran bir nevi ele geçiren oluşumların etkisini biraz daha yoğun şekilde iç mekânda görmek mümkündür. Binanın iç mekanlarında ilerlemeye devam ettikçe kendilerinden önce gelen askerlerin vücutlarının, önceki sahnelerde görülen renkli floral yapılarla iç içe geçmiş olduğu bir duvarla karşılaşırlar (Şekil 10). Karargâhın salt bir fiziksel yapı olmaktan çıkarak, kırılmaların sebep olduğu başkalaşımlarla canlı, cansız, insan, bitki, mekân gibi kavramların iç içe geçerek yeni bir morfolojik gerçeklik kurgusu yansıtılması olarak yorumlanmaktadır.

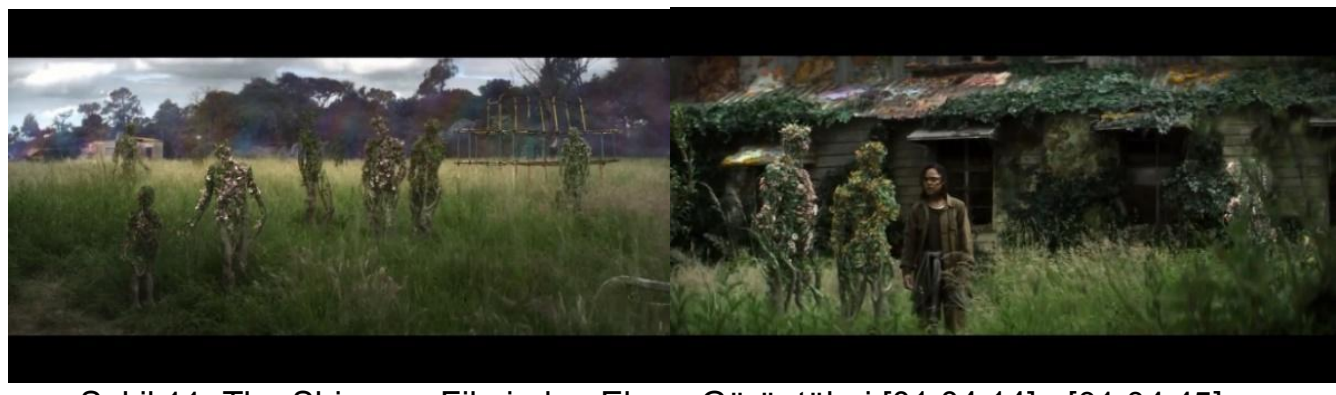

Şekil 11: The Shimmer Filminden Ekran Görüntüleri [01:04:14] - [01:04:45]

Terk edilmiş ahşap yapılar insan kullanımından uzak kaldığı süre dahilinde bitkiler tarafından sarmalanarak doğa tarafından kamufle edilir duruma gelir (Şekil 11). Geniş arazideki insan şeklinde büyümüş bitkilerle karşılaşırlar. Lena tarafından bitkilerin yaprakları incelendiği takdirde, DNA diziliminden vücut planını ve fiziksel yapıyı belirleyen insan hox genleriyle karşılaşılacağı söylenir.

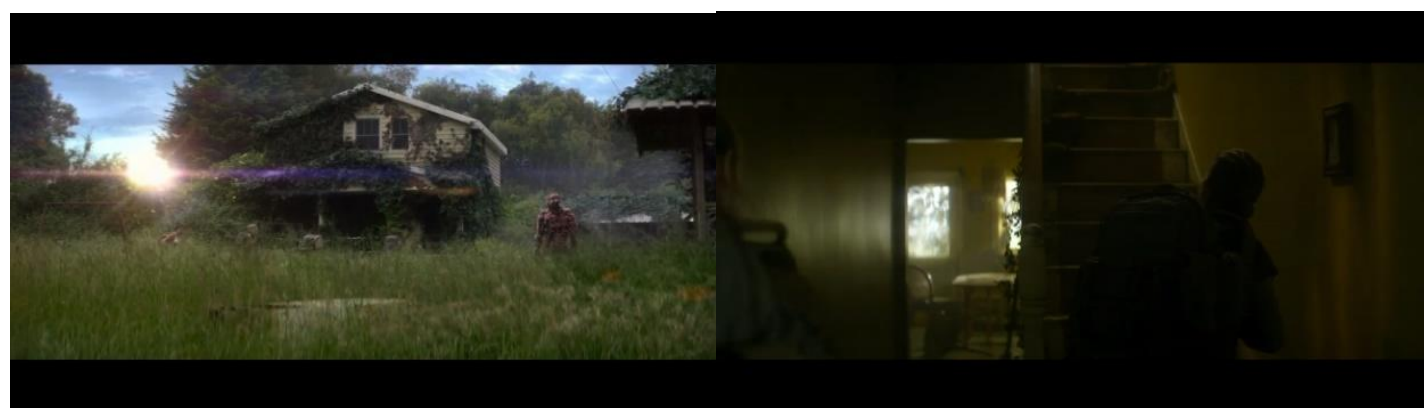

Şekil 12: The Shimmer Filminden Ekran Görüntüleri [01:06:27] - [01:06:46]

Dinlenmek için geldikleri arazide yöneldikleri ev Lena'nın The Shimmer'a gelmeden önce yaşadığı evin aynısıdır (Şekil 12). Aynı mekânın bölge içinde tekrar kullanımıyla gerek The Shimmer'ın yeni bir gerçeklik yarattığı vurgulanmış gerekse hücrelerin bölünerek sürekli bir çoğalma ve kopyalanma haline vurgu yapılmıştır. 


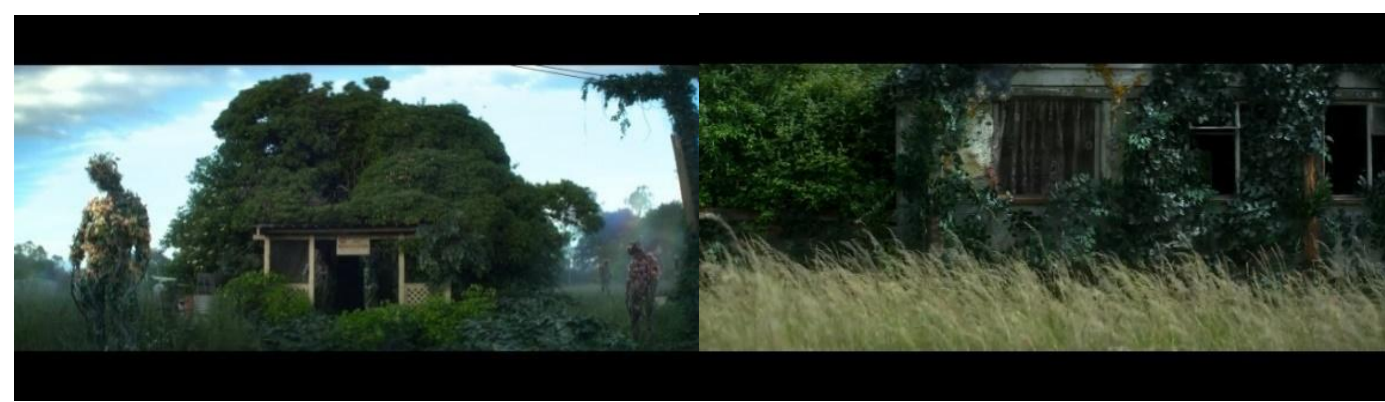

Şekil 13: The Shimmer Filminden Ekran Görüntüleri [01:18:34] - [01:18:38]

İnsan müdahalesinin kesildiği yıllar içinde gelişen bitkiler ile ve organizmaların evler üzerinde de etki göstermesiyle birlikte doğal çevre ile yapılı çevre ayrımının keskinliğinin yok olduğu görülür. Mimari mekân ve doğa arasındaki bu muğlaklığın artmasının yanında, canlılar üzerinde de aynı etkiler gözlenir (Şekil 13). Bölge DNA'lar için bir prizma görevi görmektedir. Profesör Lena'nın kendi kanından aldığı örneği incelediğinde karargâhta aldığı örneklerde olduğu gibi hücrelerin hızla parçalanıp çoğaldığını ve başkalaştığını gözlemler.

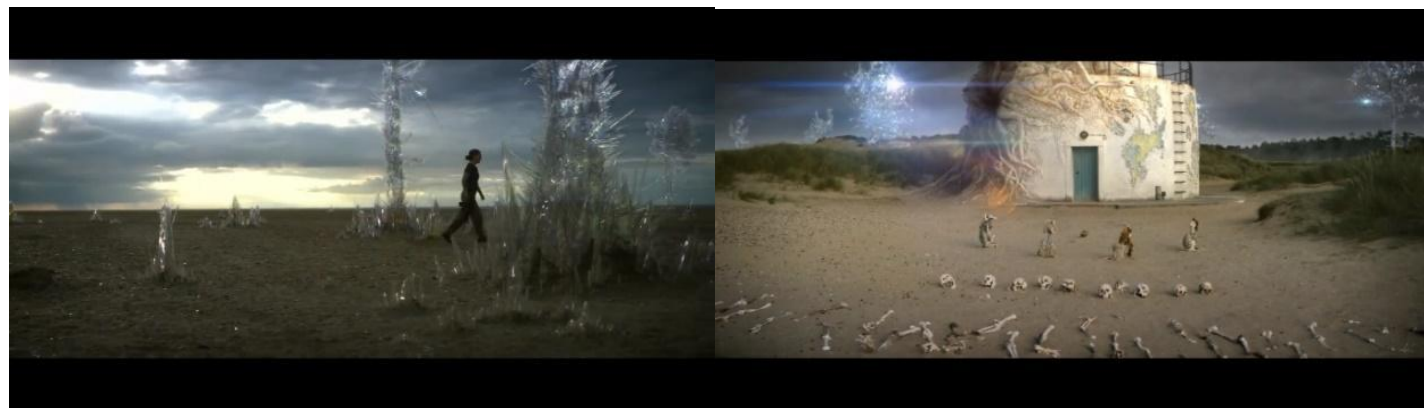

Şekil 14: The Shimmer Filminden Ekran Görüntüleri [01:24:12] - [01:25:12]

Lena ormanın içinden geçerek sahile ulaştığında, sahilden başlayan ve geniş bir arazi boyunca uzanan farklı aralıklarla gelişi güzel sıralanmış ve farklı boyutlarda kar tanelerinin kümelenmesiyle oluşmuş kristalleri andıran ağaç benzeri formlarla karşılaşır (Şekil, 14). Ortasında ise önünde çeşitli kafatası ve kemiklerin bulunduğu, zeminden başlayıp duvarları tırmanarak yapının cephesini saran kemiksi bir maddeden meydana geldiği izlenimi uyandıran dallarla sarılmış halde fener bulunur.

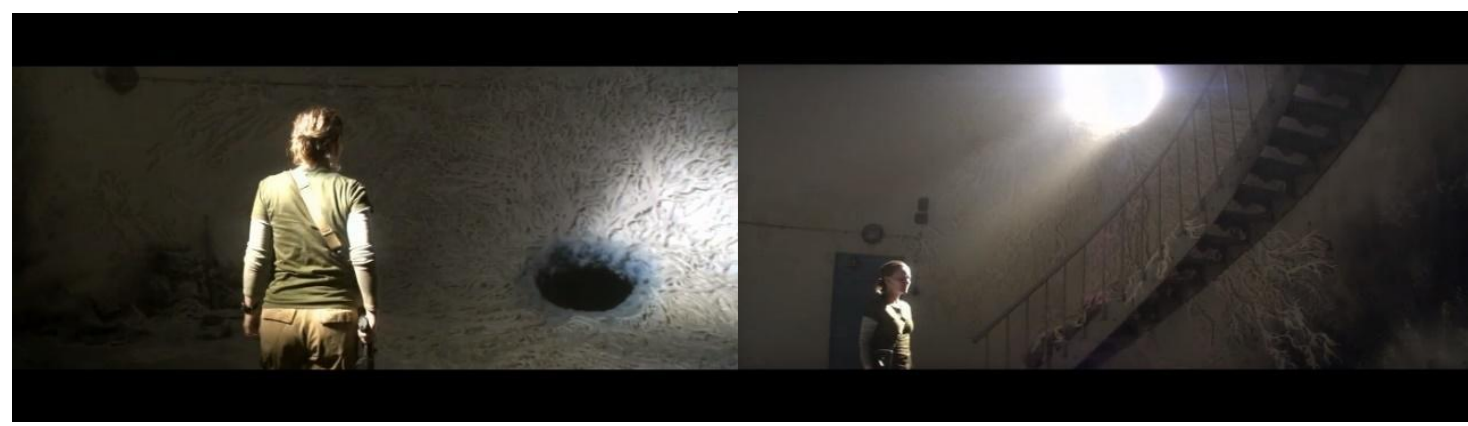

Şekil 15: The Shimmer Filminden Ekran Görüntüleri [01:25:30] - [01:25:36]

İç mekân da aynı şekilde cephedeki sarmaşık görünümünde beyaz dal benzeri formlarla sarmalanmıştır (Şekil 15). Fenerin zemininde kemiksi sarmaşık formların yoğunlaşarak merkezine doğru aldığı meteor tarafından açılmış bir delik görünmektedir. 


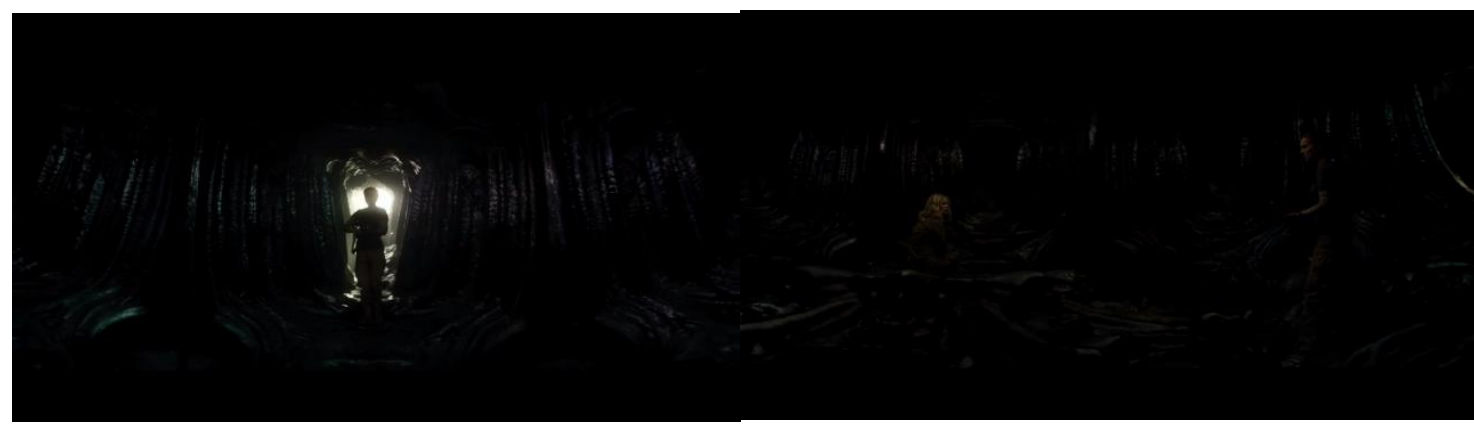

Şekil 16: The Shimmer Filminden Ekran Görüntüleri [01:31:08] - [01:31:40]

Zeminde yer alan delikten içeri girildiğinde karşılaşılan mağara zemin, duvar, tavan ayrımının bulanıklaştığı tamamen siyah bir madde ile çepeçevre sarıldığı bir mekân tasviri olarak sunulmuştur. Kendi içerisinde hareket halinde olan yüzeyleriyle sabit gibi görünen mekân aslında bir canlı organizma gibi davranmaktadır (Şekil 16).

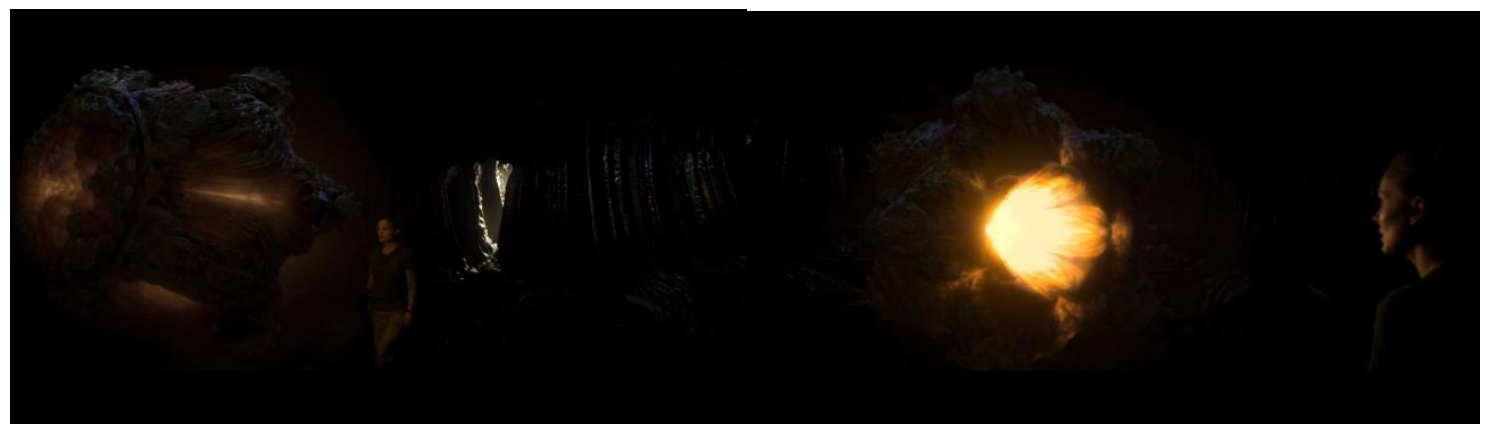

Şekil 17: The Shimmer Filminden Ekran Görüntüleri [01:34:00] - [01:34:16]

Hacimsel olarak sürekli büyüyüp küçülmekte olan amorf siyah bir form belirir. Sürekli devinim içinde içeriden dışarı, dışarıdan içeri doğru bir akış halinde form, mekân içinde mekân kurgusu yaratırken iç-dış kavramlarının arasındaki sınırı ortadan kaldırmaktadır (Şekil 17). Ambiyans olarak Gigervari bir rahim olarak tanımlanabilecek mağaranın yeniden doğuma gönderme yaptığı düşünülmektedir. Film boyunca genetik mutasyonlara maruz kalmış bir bölgenin doğal, yapılı çevre ve içindeki insanlar üzerinde oluşturduğu etkiler gösterilmektedir. Mekanlar, canlı organizmalar ve cansız nesneler Shimmer'ın yeni doğal kanunlarının etkisine girerek hızlı bir evrime uğramaktadır. Bu yeni gerçekliğin neden olduğu kırılmalarla bölgede bulunan her şey bu yeni evreni oluşturan tek büyük bir organizmaya dönüşmektedir. The Shimmer her şeyi dönüştürüp transformasyona uğratarak yeni bir şey yaratmaktadır.

\section{Değerlendirme ve Sonuç}

Çalışmada yoğunluklu olarak biyoloji bilimin içinde kullanılan bir kavram olan morfogenezin mimari disiplini ve sinema alanında mekân kurgulanımına etkileri incelenmiştir. Doğadaki evrimsel sürecin algoritmalar dahilinde mimari yaratım için bir araç olarak kullanıldığı The Interactivator modelinin incelenmesiyle morfogenez, mutasyon gibi kavramların mimari form üretimindeki etkilerine bir bakış sunulmuştur. Sistem çeşitli sensörler ile fiziksel çevrenin sıcaklık, nem, koku gibi bilgilerini algılamakta ve bir veri olarak kullanmaktadır. Bununla beraber gerek sergideki izleyiciler gerek internet üzerinden bağlanan katılımcıların genetik bilgi önerileri de süreç ve sonuç üzerinde belirleyici rol oynamaktadır. Model yaratımı sürecinde bahsedilen bu dış etkiler dijital ortamda doğal seçilim şartlarını simüle etmekte ve izleyicileri de bu işleyişe dahil ederek etkileşimli bir mimari modele ulaşılmaktadır. 
Günümüz koşullarında bilgisayar ortamında simüle edilen mimari mekân kurgusu ve form üretimi yönteminin gelecek mekân pratikleri dahilinde reel mekanlara dönüşmesi beklenmektedir. Değişen ekolojik koşullar, gelişen teknoloji, disiplinlerarası çalışma yönelimlerinin yoğunlaşması, modüler ve fonksiyonel, sürdürülebilir tasarıma eğilme gerekliliği gibi konular doğrultusunda, geleceğin mimari tasarımında çevresel koşullar karşısında canlı bir organizma gibi adapte olan, kendisini gerek form gerek malzeme açısından transforme eden, kullanıcısına çok fonksiyonlu kullanım olanakları sunan mimari mekân üretim kurgularının hâkim olacağı beklenmektedir. Mutasyon, çaprazlama, tekrarlama gibi kavramlar mimari model üretiminde kullanıldığı gibi bilim kurgu sinemasındaki mekân yaratımını da etkilemektedir.

Annihilation filminde evrim ve beraberinde getirdiği mutasyon kavramlarının bitki, hayvan, insan gibi canlıların morfolojik özelliklerini başkalaştırması görülmektedir. Hücrelerin hızla bölünerek çoğalması ve bu çoğalma esnasında başkalaşma durumunun etkileri doğal ve yapılı çevre üzerinde de gözlenmektedir. Mutasyonlar yeni bir gerçeklik kurgusu yaratarak canlı, cansız, doğal çevre, yapılı çevre sınırlarını bulanıklaştırarak izleyicinin fiziksel çevre ve insan ilişkilerini düşünmeye sevk etmektedir. Bu bağlamda film, doğal ve yapay çevre ayrımını muğlaklaştırmasının yanında, mekânsal statik ve dinamik olma halini de tartışmaya açılmaktadır. Bölgenin çevresini üç boyutlu olarak saran çok renkli, yansıtıcı, akışkan bir tabaka şeklinde gösterilen duvarın hareket halinde oluşu bu sorgulamaya yol açan kurgulardan biridir. Bir diğeri ise; meteorun çarptığı fenerin iç mekân zemininde bulunan delikten girilen, tüm yüzeyleri aynı dal benzeri oluşumlarla örülmüş monokrom mağaranın duvarlarında lineer bir akış şeklinde kendini gösteren devinimdir. Mekân kurguları içinde doğanın mekanlarda morfolojik kullanımı ve içerdikleri kinetik özellikler canlı bir organizma şeklinde davranış gösteren Morfogenetik Mimari ile paralellik göstermektedir.

Birbirinden çok farklı gibi gözüken sinema, mimarlık ve biyoloji disiplinleri, evrim kavramının mimari tasarım ve kurgusal mekanlarda kullanımı ile etkileşim halinde olan alanlar olduğu fark edilmiştir. Biyolojik bir kavramın mimariye aktarımıyla oluşan bir tasarım yaklaşımının izleri filmin mekân kurgularına yansımıştır. Bilgisayarın bir mimari sunum aracı olarak kullanılmasının evrilerek, mimari tasarım sürecinde mimar ile beraber aktif rol oynaması gibi değişimlerle beraber günümüzün ütopyaları olarak değerlendirilebilecek, bilim kurgu sinemasında çoklukla kullanılan mekân kurgularının yazılımlar aracıllı̆ıyla geleceğin mimari pratiği içerisinde kullanılacağı, doğal çevre, yapılı çevre ve kurgusal mekân sınırlarının yumuşayacağı ve mimari temsilde ortak şekilde üretimlere aktarılacağı beklenmektedir. Morfogenez, daha geniş bağlamda evrimsel işleyiş̧in mimari mekân üretim pratiği ve kurgusal mekân tasarımında benzer kullanımlara sahip olmasının yanında çeşitli farklılıklar da barındırmaktadır.

The Interactivator projesinde mutasyon, doğal seçilim gibi fenomenlerin mimari model üretimi dahilinde kullanımında, evrimsel sürecin kendisini bir araç olarak kullanarak doğada mevcut çözümlerin pragmatist bir yaklaşım dahilinde tasarım problemlerine aktarımı söz konusudur. Annihilation filminde ise dünya dışı etkilerle oluşan The Shimmer DNA'lar için bir prizma görevi görerek sınırları içine dahil olan mekânsal ve biyolojik tüm oluşumları çarpıtmakta ve dönüştürmektedir, ancak gözlendiği kadarıyla bu yeni gerçeklik yaratma durumunun pragmatist bir kullanımı söz konusu değildir. 


\section{Kaynaklar}

Ahmed, M. (2015). Bio-Digital Morphogenesis In Architecture An Application on DigitalBotanic Architecture Faculty of Engineering (Yüksek Lisans Tezi). Alexandria Üniversitesi, İskenderiye, s.7-82.

Bentley, P., Corne, D. (2001). Creative Evolutionary Systems, Massachusetts: Morgan Kaufmann, s.270.

Elshtwei, A.B. (2018). Computational generative design with biomimicry towards morphogenesis in digital architecture (Yüksek Lisans Tezi). Çankaya Üniversitesi, Ankara, s.75-80.

Frazer, J., Liu, X., Tang, M., ve Janssen, P. (2002). Generative and evolutionary techniques for building envelope design. Jeneratif Sanat Konferansı GA2002'de sunulan bildiri, Milano, Erişim adresi:

http://papers.cumincad.org/data/works/att/ga0202.content.pdf

Garland, A. (Yönetmen). (2018). Annihilation (Film). Londra: Paramount Pictures.

Grozdanic, L. (2012). Hygroscope-Meteorosensitive Morphology/Achim Menges\&Steffen Reichert. Erişim adresi: https://www.evolo.us/hygroscopemeteorosensitive-morphology-achim-menges-steffen-reichert/

Janssen, P. (2004). Digital Code Scripts for Generative and Evolutionary Design: De Identitate. Erişim adresi: https://www.generativedesign.com/asialink/de6.htm.

Kachri, G. (2009). Parasitic Ecologies: Extending Space Through Diffusion-limited Aggregation Models (Yüksek Lisans Tezi) .UCL, Londra, s.9.

İçmeli, B., M. (2004). Digital Morphogenesis In Architectural Design, Erişim adresi: https://www.academia.edu/5041153/Digital_Morphogenesis_in_Architectural_Design.

Reichert, S., Menges, A., \& Correa, D. (2015). Meteorosensitive architecture: Biomimetic building skins based on materially embedded and hygroscopically enabled responsiveness. Computer-Aided Design, 60, s.50-69. Erişim adresi: https://www.sciencedirect.com/science/article/pii/S0010448514000438?via\%3Dihub

Roudavski, S. (2009). Towards morphogenesis in architecture. International journal of architectural computing, 7(3), s.348-358. Erişim adresi: https://www.researchgate.net/publication/237403020_Towards_Morphogenesis_in_Arc hitecture

Vural, S., Avinç, G. (2015, Haziran). Doğadan Esinli Geleneksel ve Sayısal Tasarım Yöntemlerinin Yaşam Kriterlerine Göre Değerlendirilmesi, IX. Mimarlıkta Sayısal Tasarım Ulusal Sempozyumu, Özyeğin Üniversitesi Mimarlık ve Tasarım Fakültesi, İstanbul. Erişim adresi:

https://www.academia.edu/34978744/Dog_adan_Esinli_Geleneksel_ve_Say\%C4\%B1s al_Tasar\%C4\%B1m_Yo_ntemlerinin_Yas_am_Kriterlerine_Go_re_Deg_erlendirilmesi_ .pdf. 